RESEARCH NOTE

\section{Ultrastructure of Cell Renewal in the Midgut of Termites}

\section{Cruz-Landim, AM Costa-Leonardo}

Centro de Estudos de Insetos Sociais, Departamento de Biologia, Instituto de Biociências, UNESP, Caixa

Postal 199, 13506-900 Rio Claro, SP, Brasil

Key words: midgut - digestive cells - generative cells - epithelium renewal - Isoptera

The individual cells of most tissues of an organism have a shorter life span than the organism itself. So, in order to maintain the organism's integrity, a certain degree of cellular substitution must occur during life. Generally the substitution occurs by steam cells division, but in insects, mitosis is absent or is very rare in adulthood. In these cases a certain amount of undifferentiated cells are responsible for the replacement of the worn ones.

The insects midgut is an example of this late condition. At least two types of cells are present in the adult: (1) the digestive, functional or differentiated cells and (2) the generative or undifferentiated cells (HL House 1965 In M Rockstein The Physiology of Insecta, vol. II, Academic Press, N.Y.)

In the termites midgut the digestive cells are columnar and present short microvilli in the apical pole, supported by a microfibrilar cytoskeleton which continues into the terminal network (Fig. 1). Usually they have many folds of the plasmic membrane associated with mitochondria on the basal pole (Fig. 1). As these cells age, some deterioration may be observed, mainly in the apical zone. The aging of the cells is characterized by the loss of electron-density of the apical cytoplasm besides the appearance of large autophagic vacuoles and myelin figures (Figs 1,2).

The generative cells form nests inside the functional epithelium. The cells, in the nests sit over the epithelial basal lamina, but do not emerge into the epithelial surface. These cells are always differentiating since a digestive cell needs to be replaced. Then, they are transformed into functional or digestive ones. The process is marked by a straightening of some of the outer cells of the nest, by the development of their organelles, by the production of microvilli in the luminal surface and by appearance of invaginations of the plasmic membrane in the basal surface. In the replacement process, the cellular contacts between the digestive cells apparently become weak and the intercellular space appears enlarged. The damaged digestive cells are pushed up by the unclasping of the generative cells and are seen displayed parallel to the epithelial surface (Fig. 2) before being eliminated into the lumen. The cells undertaking the elimination process have nuclei parallel to the surface, desorganized microvilli (Figs 3,4) and several types of autophagic structures, like myelin figures and dense lysosome-like granules (Figs 2, $3,4)$. However, the mitochondria and the endoplasmic reticulum apparently remain intact, and the nuclei present a less condensed chromatin than the nuclei of normal cells. These cells are separated from the subjacent ones by membranes parallel to the epithelial surface (Fig. 2).The exact moment of the cellular elimination was not captured in the preparations, but cellular debris were observed in the lumen .

The autophagic vacuoles present in the dying epithelial cells of the termite midgut are very similar to the apoptotic bodies (MJ Arends, AH Wyllie 1991, Int Rev Exp Pathol 32: 223-254) and they have already been described for the mature state of epithelial cells in other termites (AM CostaLeonardo 1995 Naturalia, in press). The failure of the digestive cells may be regarded as a natural process of programmed cell death that may be under the influence of external conditions which probably accelerate the process, like the almost certain possibility of cell damage caused by food ingested by the insect.

In insects the generative cells do not divide, but in the studied neuter caste of termites some cell division was observed. However, this occurrence can not be considered an exception since the neuter caste in Isoptera is constituted by immature forms and not by adults. In termites the only adults are the alates, the reproductive forms.

\footnotetext{
* Financial support from CNPq (Proc. 520987/93-4), FINEP (Conv. 66.94.0235.00) and FAPESP (Proc. 92/ 4700-9).

Received 30 May 1995

Accepted 17 October 1995
} 


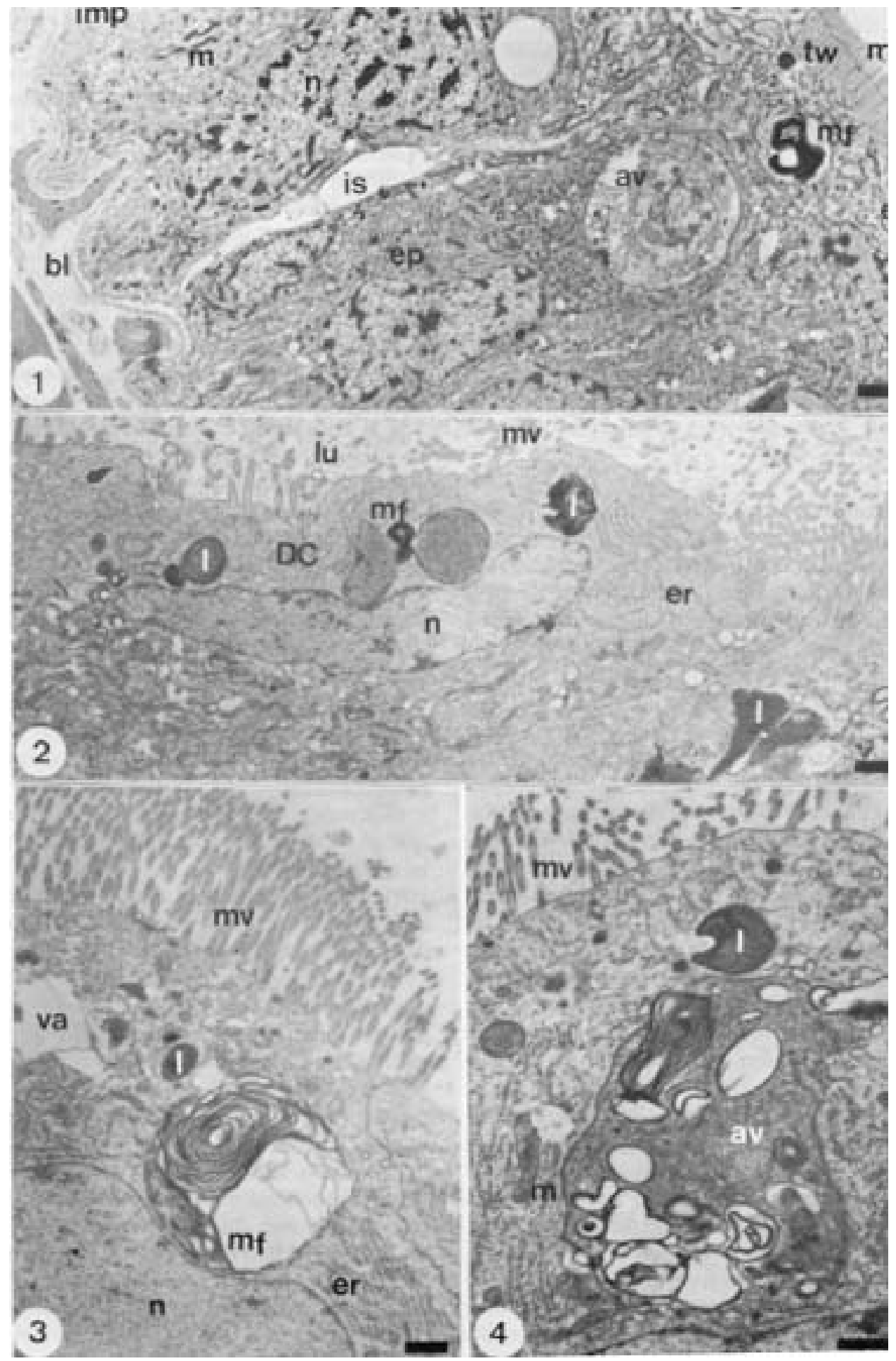

Fig. 1: midgut epithelium (ep) of Anoplotermes $\mathrm{sp} . \mathrm{bl}=$ basal lamina; $\mathrm{imp}=$ invaginations of plasmic membrane; $\mathrm{n}=\mathrm{nuclei} ; \mathrm{m}=$ mitochondria; $\mathrm{er}=$ rough endoplasmic reticulum; $\mathrm{av}=$ autophagic vacuoles; $\mathrm{mf}=$ myelin figure; $\mathrm{mv}=$ microvilli; $\mathrm{tw}=$ terminal web; is $=$ intercellular space. $\mathrm{Bar}=1 \mu \mathrm{m}$. Fig. 2 : digestive cell (DC) being pushed up into the midgut of Anoplotermes sp. $1=1 \mathrm{ysosome} ; \mathrm{mf}$ $=$ myelin figure $; \mathrm{mv}=$ microvilli; $\mathrm{er}=$ rough endoplasmic reticulum; $\mathrm{n}=$ nucleus; $\mathrm{lu}=$ lumen. $\mathrm{Bar}=1 \mu \mathrm{m}$. Fig. 3 : apical border of an epithelial cell in midgut of Rugitermes niger. $\mathrm{mv}=$ microvilli; $\mathrm{n}=$ nucleus $; \mathrm{mf}=$ myelin figure $;=$ lysosome; va = vacuole; er = rough endoplasmic reticulum. Bar $=1 \mu \mathrm{m}$. Fig. 4: autophagic vacuole (av) in a digestive cell of the Rugitermes niger midgut. $1=1 \mathrm{ysosome}$; $\mathrm{m}=$ mitochondria $\mathrm{mv}=$ microvilli. $\mathrm{Bar}=1 \mu \mathrm{m}$. 